\title{
Accidental consumption of Atta cephalotes (Hymenoptera: Formicidae) by Artibeus lituratus (Chiroptera: Phyllostomidae)
}

\section{Sebastián Montoya-Bustamante Natalya Zapata-Mesa}

Grupo de Investigación en Ecología Animal, Universidad del Valle, Cali, Colombia. sebastian093_2@ hotmail.com

Artibeus lituratus is a large-sized fruit bat that occurs along the Neotropics, from Mexico to northern Argentina, including the Lesser Antilles and Trinidad and Tobago (Marques-Aguiar, 2007). This species is mostly frugivorous, including a wide variety of fleshy fruits in their diet, however, as other Artibeus species, Cecropia (Cecropiaceae) and Ficus (Moraceae) are the most consumed plant genera (Gardner, 1977; Saldaña-Vázquez et al., 2013); therefore, these bats play important roles during successional stages in Neotropical forests (Muscarella \& Fleming, 2007).

Besides fruits, nectar (Fleming et al., 1972), leaves (Zortéa \& Mendes, 1993; Bobrowiec \& Cunha, 2010), and insects (Arata et al., 1967; Fleming et al., 1972; Heithaus et al., 1975; Zortéa \& Chiarello, 1994; Muñoz-Saba et al., 1997) have been previously reported in A. lituratus diet in variable percentages. The ingestion of food items different from fruits in Stenodermatine bats has been suggested as a strategy to increase the nitrogen intake, because this element is not abundant in most fruits (Morrison, 1980). On the other hand, according to Zortéa \& Chiarello (1994), A. lituratus chews the soft parts ingesting its fluids and expelling the harder parts in the form of oral pellets. Hence, the real proportion of insects consumed by this bat species might be underestimated.

During a 6-months research carried out in the Robles village (Jamundí municipality, Valle del Cauca Department, Colombia) in 2014, bat feces were collected to determine the diet of fruit-eating bats. This study area included farms and tropical dry forest remnants, where A. lituratus was the most generalist species, with 10 different plant species recorded in its diet, including Ficus, Psidium, Mangifera, Cecropia, and Piper species (Montoya-Bustamante et al., 2016). Within two (out of 130) different fecal samples an individual of Atta cephalotes (both workers) were found associated to Psidium guajava seeds and pulp (Figure 1).

Despite insect consumption in A. lituratus has already been reported, it is unusual to find records where those insects are identified to the species level. Zortéa \& Chiarello (1994) and Ruschi (1953 cited by Gardner, 1977) determined those consumed insects as belonging to the families Scarabeidae (Coleoptera) and Sphingidae (Lepidoptera), respectively. In both cases, these insects were capable to fly. Furthermore, there is no information about A. lituratus foraging strategies (in order to consume insects). However, the congeneric and ecologically similar species A. jamaicensis has been reported to active hunt black flies (The author is not clear about its taxonomic identification; however, we believe he was referring to Diptera: Simuliidae; Tuttle, 1968), therefore, it is expected that A. lituratus actively searches for prey in order to achieve its nitrogen intake requirements. Notwithstanding, this does not seem to be the case.

Since At. cephalotes workers can be found feeding on ripe Psidium guajava fruits, it is possible that these ants were above or inside the fruits before A. lituratus consumed the fruit. Given the small number of samples containing ants, we consider these consumptions as accidents rather than active hunt. Finally, this study reveals the importance of collecting bat's feces, and to determine correctly their content in order to understand the diet of bat species.

Acknowledgements

We thank O. Ascuntar-Osnas for ants' identification. We also thank B. González-Chávez, V. Rojas-Díaz and an anonymous reviewer for their commentaries on the manuscript.

Mammalogy Notes | Notas Mastozoológicas

Sociedad Colombiana de Mastozoología

Vol. 4 Num. 1| 2017 


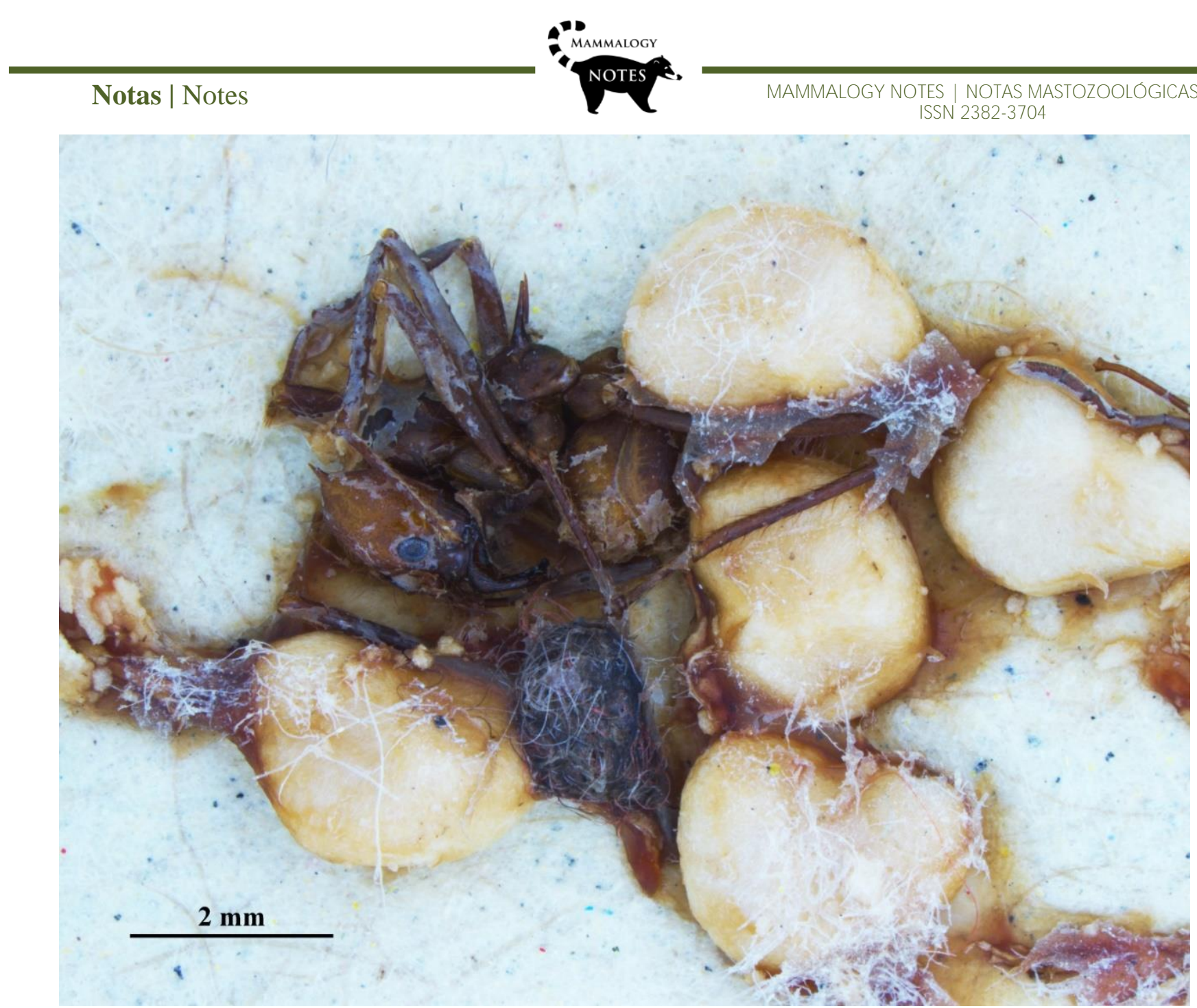

Figure 1. Individual of Atta cephalotes (Hymenoptera: Formicidae) (worker) found in feces of Artibeus lituratus in Robles, Valle del

\section{References}

Cauca, Colombia. Scale $2 \mathrm{~mm}$

ARATA, A. A., et al. 1967. Food habits of certain Colombian bats. Journal of Mammalogy 48:653-655.

BOBROWIEC, P. E. D. \& R. M. CUNHA. 2010. Leaf-consuming behavior in the big fruit-eating bat, Artibeus lituratus (Olfers, 1818) (Chiroptera: Phyllostomidae), in an urban area of Southeastern Brazil. Chiroptera Neotropical 16:595-599.

FLEMING, T. H., et al. 1972. Three Central American bat communities: structure, reproductive cycles, and movement patterns. Ecology 56:556-569.

GARDNER A. L. 1977. Feeding habits. Pp. 293-350 in Biology of Bats of the New World Family Phyllostomatidae Part II. (Baker, R. J, et al. eds.), Special Publications No. 13, Museum of Texas Tech University. Lubbock, USA.

MARQUES-AGUIAR, S. A. 2007. Genus Artibeus Leach, 1821. Pp. 301-320 in Mammals of South America Volume 1: Marsupials, Xenarthrans, Shrews and Bats (Gardner, A.L. ed.), University of Chicago Press. Chicago, USA.

HEITHAUS, E. R., et al.. 1975. Foraging patterns and resource utilization in seven species of bats in a seasonal tropical forest. Ecology 56:841-854.

MONTOYA-BUSTAMANTE, S., et al. 2016. Interactions between frugivorous bats (Chiroptera: Phyllostomidae) and Piper tuberculatum (Piperaceae) in a tropical dry forest in Valle del Cauca, Colombia. Revista de Biología Tropical/International Journal of Tropical Biology and Conservation 64: 701-713.

MUSCARELLA, R. \& T. H. FLEMING. 2007. The role of frugivorous bats in tropical forest succession. Biological reviews 82:573-590.

MORRISON, D. W. 1980. Efficiency of food utilization by fruit bats. Oecologia 45:270-273.

MUÑOZ-SABA, Y., et al. 1997. Ecología de los murciélagos antófilos del sector La Curia, Serranía La Macarena (Colombia). Rev. Acad. Colomb. Cienc. 21:473-486.

RUSCHI, A. 1953. Morcegos do Estado do Espírito Santo XVII. Familia Phyllostomidae. Descrição das espécies Artibeus jamaicensis lituratus e Vampyrops lineatus, com algumas observações biológicas a respeito. Bol. Mus. Biol. Prof. Mello-Leitão, Santa Teresa, Zool. 20:1-8.

TUTTLE, M. D. 1968. Feeding habits of Artibeus jamaicensis. Journal of Mammalogy 49:787.

ZORTÉA, M. \& A. G. CHIARELLO. 1994. Observations on the big fruit-eating bat, Artibeus lituratus, in an urban reserve of South-east Brazil. Mammalia 58: 665-670.

ZORTÉA, M. \& S. L. MENDES. 1993. Folivory in the Big Fruit-eating bat Artibeus lituratus (Chiroptera: Phyllostomidae) in eastern Brazil. Journal of Tropical Ecology 9:117-120.

\section{Mammalogy Notes | Notas Mastozoológicas \\ Sociedad Colombiana de Mastozoología \\ Vol. 4 Num. 1| 2017}

